\title{
PENGARUH KENAKALAN REMAJA TERHADAP TINGKAT KECEMASAN ORANG TUA DI KECAMATAN GENDING KABUPATEN PROBOLINGGO
}

\author{
Muthmainnah Zakiyyah \\ Prodi DIII Kebidanan STIKES Hafshawaty Pesantren Zainul Hasan \\ Email: iinlira20@gmail.com
}

\begin{abstract}
Abstrak
Kenakalan remaja tidak hanya menimbulkan kegelisahan bagi masyarakat, tetapi juga bisa menimbulkan kecemasan pada orang tua. Hasil dari studi pendahuluan dari 36 orang remaja dan orang tuanya, mendapatkan bahwa $100 \%$ remaja telah melakukan kenakalan remaja dengan tipe kenakalan: penipuan $30 \%$, pencurian $25 \%$, tawuran $20 \%$, pemerasan 15\%, dan lain-lain 10\%. Data tentang kecemasan orang tua diperoleh oleh $80 \%$ orang tua mengalami kecemasan dan $20 \%$ orang tua tidak cemas. Tujuan dari penelitian ini adalah untuk mengetahui pengaruh kenakalan remaja terhadap tingkat kecemasan orang tua yang mempunyai anak usia remaja di Kecamatan Gending Kabupaten Probolinggo. Desain penelitian yang digunakan adalah analitik. Penelitian ini dilaksanakan pada tanggal 9 Mei - 22 Mei 2019 yang populasinya diambil dari 36 responden remaja dan orang tuanya yang memenuhi syarat dengan metode total sampling dengan jumlah sampel 36 responden. Instrumen ukur menggunakan daftar periksa dan daftar pertanyaan. Dari hasil uji korelasi spearman Rho dengan sistem 0,000 <0,05. Dengan demikian Ho menolak, H1 diterima, artinya ada Pengaruh kenakalan remaja terhadap tingkat kecemasan orang tua yang mempunyai anak usia remaja. Dari penelitian ini diharapkan orang tua dapat mengatasi kecemasan yang dihadapi itu.
\end{abstract}

Kata Kunci : kenakalan, remaja, kecemasan, orang tua, usia

\begin{abstract}
Juvenile delinquency not only causes anxiety for the community, but can also cause anxiety in the elderly. The results of a preliminary study of 36 teenagers and their parents, found that $80 \%$ of adolescents had committed juvenile delinquency with delinquency type: $30 \%$ fraud, 25\% theft, $20 \%$ brawl, 15 extortion and $10 \%$ others. Data on parental anxiety was obtained by $80 \%$ of parents experiencing anxiety and $20 \%$ of parents not worried. The purpose of this study was to determine the effect of juvenile delinquency on anxiety levels of parents who have teenagers in Gending District, Probolinggo Regency. The research design used is analytic. This research was conducted on May 9 to May 22 2019, the population was taken from 36 teenage respondents and their parents who met the requirements with a total sampling method with a total sample of 36 respondents. Measuring instruments use checklists and questionnaires. From the results of the Spearman Rho correlation test with a system of 0,000 <0.05. Thus Ho refused, H1 accepted, meaning that there was an influence of juvenile delinquency on the level of anxiety of parents who have teenagers. From this research parents are expected to overcome the anxiety they face.
\end{abstract}

Keywords: delinquency, teenagers, anxiety, parents, age

\section{PENDAHULUAN}

Kenakalan remaja adalah kesalahankesalahan yang dilakukan oleh remaja itu sendiri yang dapat menimbulkan kekesalan lingkungan. Hal ini merupakan gejala umum, khususnya terjadi di kota-kota besar yang kehidupannya diwarnai dengan adanya persaingan dalam memenuhi kebutuhan hidup, baik secara sehat maupun tidak sehat (Adilla, N., 2009).
Tentunya pelaku kenakalan remaja adalah anak-anak pada masa peralihan dari kanakkanak ke dewasa dan melalui masa pubertas. Banyak hal yang akan berubah pada diri remaja baik fisik maupun psikis. Mereka sedang mencari pola hidup yang paling sesuai dan sering melalui metode coba-coba, walaupun melalui banyak kesalahan. Kesalahan-kesalahan yang merugikan lingkungan inilah yang dapat menimbulkan kecemasan orang tua (Anganthi, dkk, 2010). 
Kecemasan adalah semacam kegelisahan, kekhawatiran, dan ketakutan terhadap terhadap sesuatu yang tidak jelas, yang difus dan yang mempunyai ciri yang mengazab pada seseorang. Kecemasan dipengaruhi oleh dua faktor, yaitu faktor internal dan eksternal. Kenakalan remaja merupakan salah satu faktor eksternal yang dapat menimbulkan kecemasan bagi orang tua yang mempunyai anak usia remaja. Mereka merasa khawatir jika anak mereka akan terpengaruh untuk melakukan kenakalan remaja (Patinus, R, 2014).

Meningkatnya kasus kenakalan remaja akhir ini dapat kita lihat dari beberapa media online, televisi, maupun surat kabar. Bila ditelusuri secara mendalam perkembangan kenakalan remaja banyak di pengaruhi dari kehidupan keluarga dan masyarakat sebaimana di kemukakan oleh Kartini Kartono (1992) keluarga memiliki peran besar bagi timbulnya kenakalan remaja di antaranya yaitu: pola criminal orang tua, tempramen orang tua, sikap ketidakpuasan terhadap orang tua, kualitas rumah tangga (perceraian, kematian, poligami), dan kurangnya perhatian dan kasih sayang. Bila kita lihat dari lingkungan masyarakat modern ada beberapa hal yang mendorong timbulnya kenakalan remaja yaitu perubahan struktur keluarga, frustasi dan penyimpangan sosial. Selain itu pengaruh budaya asing juga memiliki peran besar dalam terjadinya kenakalan remaja yaitu gaya hidup konsumtif, mewah, polah hidup bebas, tidak mengenal sopan santun, bebas berpakaian, penggunaan obat obatan terlarang, minuman keras dan lain-lain (Sumara, 2017).

Berdasarkan studi pendahuluan yang diadakan di Kecamatan Gending, Kabupaten Probolinggo pada bulan April 2019 terhadap 36 responden remaja dan orang tua, didapatkan prosentase $100 \%$ remaja pernah melakukan kenakalan remaja. Adapun prosentase jenis kenakalan remaja yang mereka lakukan lakukan adalah penipuan $30 \%$, pencurian $25 \%$, tawuran $20 \%$, pemerasan $15 \%$, dan lain-lain $10 \%$. Data tentang kecemasan orang tua diperoleh $80 \%$ orang tua merasa cemas dan $20 \%$ orang tua merasa tidak cemas.

Masalah kenakalan remaja mulai mendapat perhatian yang khusus sejak dibentuknya suatu peradilan untuk anak-anak nakal atau juvenille court pada tahun 1899 di Cook Country, Illionis, Amerika Serikat. Pada saat itu, peradilan tersebut berfungsi sebagai pengganti orang tua si anak (in loco parents) yang memutuskan perkara untuk kepentingan si anak dan masyarakat. Dalam 13 tahun masih dianggap wajar, sedangkan kenakalan diatas 18 tahun dianggap merupakan kejahatan (Varyani, 2013).

Hal ini dapat menyebabkan kecemasan bagi orang tua yang mempunyai anak remaja. Oleh karena itu hendaknya orang tua berkenan menerima anak usia remaja dengan lebih hatihati. Orang tua harus memberikan kepercayaan dan kebebasan yang bertanggung jawab kepada remaja, serta mampu menjadi teladan di depan, di tengah membangkitkan semangat dan dibelakang mengawasi tingkah laku remaja. Dengan demikian diharapkan masalah kenakalan remaja dapat berkurang.

Penelitian ini bertujuan untuk mengidentifikasi pengaruh kenakalan remaja terhadap tingkat kecemasan orang tua yang mempunyai anak usia remaja.

\section{METODE PENELITIAN}

Penelitian ini menggunakan desain analitik korelasi yaitu penelitian yang mempelajari hubungan antara variabel dependen dengan variabel independen. Tempat penelitian yaitu Kecamatan Gending Kabupaten Probolinggo. Waktu Penelitian selama 1 bulan yang meliputi kegiatan penyusunan proposal, pelaksanaan penelitian dan penyusunan laporan akhir penelitian. Pelaksanaan penelitian dilakukan mulai tanggal 9 sampi 22 Mei 2019. Populasi penelitian ini yaitu remaja usia 14-21 tahun sebanyak 36 responden. Teknik pengambilan sampel yaitu total sampling. Sampel yaitu remaja usia 14-21 tahun sebanyak 36 responden. Variabel independen pada penelitian ini kenakalan remaja dan variabel dependen adalah tingkat kecemasan orang tua yang mempunyai anak usia remaja. Instrument penelitian yang digunakan berupa kuesioner yang berisi butir pertanyaan tentang data umum meliputi identitas responden dan identitas orang tua, sedangkan data khusus meliputi kenakalan remaja dan kecemasan orang tua. Penilaian kuesioner didasarkan atas jawaban responden yang dikelompokkan menurut kategori ya $=1$ dan tidak $=2$ terhadap pernyataan yang diajukan. Analisis data dilakukan dengan uji korelasi Spearman Rho dengan tingkat kemaknaan $\mathrm{p} \leq 0.05$. 


\section{HASIL DAN PEMBAHASAN}

Hasil penelitian tentang pengaruh kenakalan remaja terhadap kecemasan orang tua adalah sebagai berikut :

Tabel 1. Pengaruh Kenakalan Remaja terhadap Tingkat Kecemasan Orang Tua yang Mempunyai Anak Usia Remaja di Kecamatan Gending Kabupaten Probolinggo

\begin{tabular}{|c|c|c|c|c|c|c|c|c|c|c|}
\hline \multirow{3}{*}{ Kenakalan Remaja } & \multicolumn{8}{|c|}{ Kecemasan } & & \\
\hline & \multicolumn{2}{|c|}{ Ringan } & \multicolumn{2}{|c|}{ Sedang } & \multicolumn{2}{|c|}{ Berat } & \multicolumn{2}{|c|}{$\begin{array}{c}\text { Berat Sekali } \\
\text { (panik) }\end{array}$} & \multicolumn{2}{|c|}{ Total } \\
\hline & $\mathrm{f}$ & $\%$ & f & $\%$ & $\mathrm{f}$ & $\%$ & $\mathrm{f}$ & $\%$ & $\mathrm{f}$ & $\%$ \\
\hline Ringan & 6 & 16.7 & 0 & 0 & 0 & 0 & 0 & 0 & 6 & 16.7 \\
\hline Sedang & 3 & 8.3 & 15 & 41.7 & 0 & 0 & 0 & 0 & 18 & 50 \\
\hline Berat & 0 & 0 & 3 & 8.3 & 9 & 25 & 0 & 0 & 12 & 33.3 \\
\hline Total & 9 & 25 & 18 & 50 & 9 & 25 & 0 & 0 & 36 & 100 \\
\hline
\end{tabular}

Berdasarkan hasil penelitian menunjukkan bahwa responden remaja dengan tingkat kenakalan ringan sebanyak 6 responden $(16,7 \%)$ dengan orang tuanya cenderung mengalami kecemasan ringan sebanyak 6 orang $(16,7 \%)$, orang tua dengan kecemasan sedang sebanyak 0 orang $(0 \%)$, dan orang tua dengan kecemasan berat sebanyak 0 orang $(0 \%)$. Responden remaja dengan tingkatan kenakalan remaja sedang sebanyak 18 orang $(50 \%)$ dengan orang tua yang mengalami kecemasan ringan sebanyak 3 orang $(8,3 \%)$, orang tua yang mengalami kecemasan sedang sebanyak 15 orang $(41,7 \%)$, dan orang tua yang mengalami kecemasan berat sebanyak 0 orang (0\%). Responden dengan tingkat kenakalan berat sebanyak 12 orang $(33,3 \%)$ dengan orang tua yang mengalami kecemasan ringan sebanyak 0 orang $(0 \%)$, orang tua dengan kecemasan sedang sebanyak 3 orang $(8,3 \%)$ dan orang tua yang mengalami kecemasan berat sebanyak 9 orang (25\%).

Analisis uji statistik korelasi Spearman Rho dengan sistem SPSS, dengan tingkat kemaknaan 0.05 , didapat $\rho<\alpha$, yaitu $0,000<0.05$ yang berarti H1 diterima, hal ini menunjukkan bahwa ada pengaruh yang signifikan kenakalan remaja terhadap kecemasan orang tua yang mempunyai anak usia remaja di Kecamatan Gending Kabupaten Probolinggo.

Bentuk kenakalan remaja menurut Setiadi, 2011 terdiri dari pertama, kenakalan ringan yaitu kenakalan yang melanggar aturan-aturan yang ada disekitar lingkungan misalnya lingkungan sekolah dan lingkungan keluarga. Kenakalan ini tidak diatur oleh undang-undang dan tidak dapat dikategorikan sebagai pelanggaran hukum. Contoh kenalakan ringan yaitu berbohong kepada orang tua, keluar rumah tanpa pamit, bolos sekolah, berkelahi, keluyuran di malam hari dan lain-lain. Kedua, kenakalan sedang yaitu jenis kenakalan yang menjurus pada pelanggaran dan kejahatan dimana kenakalan ini diatur oleh hukum dan dapat merugikan masyarakat. Contoh kenakalan sedang yaitu mengambil barang atau hak milik orang lain tanpa izin, mengendarai mobil atau sepeda tanpa Surat Izin Mengemudi (SIM) dan lain-lain. Ketiga, kenakalan berat yaitu kenakalan yang melanggar hukum dan mengarah kepada tindakan kriminal. Contoh kenakalan berat yaitu penyalahgunaan narkotika, hubungan seks di luar nikah, pemerkosaan, pencurian dan lain-lain.

Stuart dan Sundeen (1995) membagi kecemasan menjadi 3 tingkatan yaitu pertama, Kecemasan ringan berhubungan dengan ketegangan akan peristiwa kehidupan sehari-hari. Pada tingkat ini lahan persepsi melebar dan individu akan berhati-hati dan waspada. Individu terdorong untuk belajar yang akan menghasilkan pertumbuhan dan kreativitas. Gejala kecemasan ringan yaitu respon fisiologi meliputi sesekali nafas pendek, nadi dan tekanan darah naik, gejala ringan pada lambung, muka berkerut dan bibir bergetar; respon kognitif meliputi mampu menerima rangsangan yang kompleks, konsentrasi pada masalah dan menyelesaikan masalah secara efektif; respon perilaku dan emosi meliputi tidak dapat duduk tenang, tremor halus pada tangan dan suara kadang-kadang meninggi.

Kedua, kecemasan sedang. Pada tingkat ini lahan persepsi terhadap lingkungan menurun atau individu lebih memfokuskan pada hal penting saat itu dan mengesampingkan hal lain, sehingga seseorang mengalami perhatian yang selektif namun dapat melakukan sesuatu yang lebih terarah. Gejala kecemasan sedang yaitu respon fisiologis meliputi sering nafas pendek, Nadi 
ekstra systole dan tekanan darah naik, Mulut kering, Anorexia, Diare/konstipasi dan Gelisah; Respon Kognitif meliputi Rangsangan Luar tidak mampu diterima dan Berfokus pada apa yang menjadi perhatiannya; Respon Perilaku dan Emosi meliputi Gerakan tersentak-sentak (meremas tangan), Bicara banyak dan lebih cepat serta Perasaan tidak nyaman.

Ketiga, kecemasan berat. Pada kecemasan berat lahan persepsi menjadi sempit. Individu cenderung memikirkan hal yang kecil saja dan mengabaikan hal-hal yang lain. Individu tidak mampu berfikir berat lagi dan membutuhkan banyak pengarahan atau tuntutan. Sangat membatasi lahan persepsi seseorang. Sesorang cenderung memusatkan pada sesuatu yang terinci, spesifik dan tidak dapat berfikir tentang hal lain. Semua perilaku ditujukan untuk mengurangi ketegangan. Orang tersebut memerlukan banyak pengarahan sehingga dapat memusatkan pada suatu objek lain. Gejala kecemasan berat yaitu Respon Fisiologis meliputi Sering nafas pendek, Nadi dan tekanan darah naik, Berkeringat dan sakit kepala serta Penglihatan kabur; Respon Kognitif meliputi Lapang persepsi sangat menyempit dan Tidak mampu menyelesaikan masalah; Respon Perilaku dan Emosi meliputi Perasaan ancaman meningkat, Verbalisasi cepat dan Blocking atau menutup diri (Aziz, 2012).

Hal ini dapat dipahami bahwa kecemasan dapat dipengaruhi oleh beberapa faktor diantaranya faktor eksternal. Kecemasan yang dialami orang tua yang mempunyai anak usia remaja ini dapat disebabkan oleh kenakalan remaja yang dilakukan oleh anaknya tersebut. Semakin tinggi tingkat kenakalan remaja yang dilakukan oleh si anak, maka semakin tinggi pula kecemasan yang dirasakan oleh orang tua si anak tersebut. Solusi dari persoalan-persoalan yang menjadi penyebab dalam kenakalan remaja tersebut perlu adanya perhatian khusus serta pemahaman yang baik serta penanganan yang tepat terhadap remaja merupakan faktor penting bagi keberhasilan remaja di kehidupan selanjutnya, mengingat masa ini merupakan masa yang paling menentukan. Selain itu juga

\section{REFERENSI}

Adilla, N. (2009). Pengaruh Kontrol Sosial terhadap Perilaku Bullying Pelajar di Sekolah Menengah Pertama. Jurnal Kriminologi Indonesia. Volume 5 : 56- 66. perlu adanya kerjasama dari remaja itu sendiri, orang tua, guru dan pihak-pihak lain yang terkait agar perkembangan remaja di bidang pendidikan dan bidang-bidang lainnya dapat dilalui secara terarah, sehat dan bahagia.

\section{KESIMPULAN DAN SARAN}

\section{Kesimpulan}

Tingkat kenakalan remaja yang dilakukan oleh responden remaja di Kecamatan Gending Kabupaten Probolinggo mayoritas sedang yaitu $50 \%$. Tingkat kecemasan orang tua yang mempunyai anak usia remaja di Kecamatan Gending Kabupaten Probolinggo mayoritas sedang (50\%). Berdasarkan hasil uji korelasi Spearman Rho dengan sistem SPSS, didapat $\rho<\alpha$, yaitu $0,000<0.05$, yang berarti ada pengaruh yang signifikan antara kenakalan remaja terhadap kecemasan orang tua yang mempunyai anak usia remaja di Kecamatan Gending Kabupaten Probolinggo.

\section{Saran}

Profesi Kebidanan sebagai pemberi pelayanan kesehatan khususnya kebidanan pada usia remaja, maka perlu meningkatkan pengetahuan bidan dalam penanganan kecemasan yang terjadi pada orang tua yang mempunyai anak usia remaja yang melakukan kenakalan remaja dengan memberikan informasi tentang bagaimana penanganan kecemasan sehingga kecemasan akan menurun dan orang tua dapat menyelesaikan masalah kenakalan si anak dengan tenang.

Perlu dilakukan penelitian lebih lanjut tentang topik kenakalan remaja dengan kriteria lebih ketat dan perlu diadakan penyuluhan tentang kenakalan remaja yang dapat merusak masa depan bangsa dan negara.

Untuk remaja diharapkan dapat lebih berhati-hati dalam melakukan setiap tindakan, karena dapat berpengaruh terhadap masa depan remaja itu sendiri. Untuk orang tua diharapkan dapat lebih waspada dalam mengawasi tingkah laku anaknya, terutama pada usia remaja.

Aziz, Hidayat. (2012). Pengantar Konsep Keperawatan Dasar. Salemba Medika : Jakarta

Anganthi, N. R. A., Purwandari, E., \& Purwanto, Y. (2010). Pola delinquency penyalahgunaan napza di surakarta. 
Laporan Penelitian Fundamental Research Dikti.

Patinus, R. \&. (2014). Kenakalan Remaja Di Kalangan Siswa-Siswi SMPN 07 Sengah Temila Kecamatan Sengah Temila Kabupaten Landak. Jurnal Tesis PMIS-UNTAN-PSS. Volume $3: 1-15$.

Setiadi, Elly \& Usman. (2011). Pengantar Sosiologi : Pemahaman Fakta dan Gejala Permasalahan
Sosial, Teori, Aplikasi dan Pemecahannya. Jakarta: Kencana.

Sumara, Dadan, dkk. (2017). Kenakalan Remaja dan Penanganannya. Jurnal Penelitian dan PPM. Volume $2: 346-353$.

Varyani, S. \&. (2013). Analisis Pengendalian Sosial Perilaku Menyimpang Siswa Bermasalah di SMA. Jurnal Sosiologi. Volume $4: 21$ - 35 . 